\title{
PROSES PRODUKSI AUDIO PADA KONSER VIRTUAL "COLORCHESTRA" BATAVIA CHAMBER ORCHESTRA MENGGUNAKAN SOFTWARE DIGITAL AUDIO WORKSTATION LOGIC PRO
}

\author{
R.M. Aditya Andriyanto \\ Universitas Negeri Jakarta \\ Email:rm-aditya@unj.ac.id
}

\section{Intisari/Abstrak}

Pandemi Covid-19 menyebabkan munculnya konsep pertunjukan konser musik secara virtual sebagai alternatif penyajian karya seni musik. Penelitian ini bertujuan untuk mengetahui proses produksi audio hasil rekam karya pada Konser Virtual "Colorchestra" Batavia Chamber Orchestra menggunakan software Digital Audio Workstation Logic Pro. Selain itu, penelitian ini diharapkan dapat menambah wawasan pendidik dan peserta didik (mahasiswa) mengenai penciptaan karya mengunakan software DAW sebagai kecakapan digital literasi pendidikan musik abad-21. Metode penelitian ini menggunakan metode kualitatif deskriptif dengan pendekatan eksploratif studi dokumentasi. Pada konser virtual "Colorchestra", audio dan video sudah diproduksi sebelum penayangannya. Tahapan produksi audio yang dilakukan diantaranya proses rekam audio, editing audio, mixing dan mastering yang dilakukan pada DAW Logic Pro. Proses rekam audio dilakukan pemain secara satu-persatu, kemudian digabungkan dan diedit pada DAW. Pada proses mixing dan mastering, audio digarap sesuai dengan interpretasi conductor terhadap karya melalui pengolahan estetis frekuensi, dinamika dan panorama menggunakan DAW dari masing-masing track instrumen. Hasil akhir audio selanjutnya digabungkan dengan produksi video untuk kemudian ditayangkan menjadi konser virtual "Colorchestra" Batavia Chamber Orchestra.

Keyword: Penciptaan Karya Musik, Konser Virtual, Digital Audio Workstation.

\begin{abstract}
The Covid-19 Pandemic leads to virtual music concerts as an alternative for music performance. This study aims to understand the audio production process in Virtual Concert "Colourchestra" Batavia Chamber Orchestra using software Digital Audio Workstation (DAW) Logic Pro. This study will give more knowledge about producing music using DAW software as digital skills literacy in $21^{\text {st }}$-century music education. This study uses a qualitative descriptive method with an explorative approach and documentation study. For the virtual concert "Colourchestra", audio and video were pre-recorded before the premiere broadcast. The audio production process consists of recording, editing, mixing, and mastering using DAW Logic Pro. The audio recording session was done one by one before it was combined and edited. The mixing and Mastering process was done by the $\mathrm{BCO}$ conductor based on his interpretation of the song through the settings of frequency esthetic, dynamics, and panorama using DAW from each instrument track. The final audio was then combined with the video that was taken and edited separately. Then it is played in the premiere broadcast of Virtual "Colourchestra" Batavia Chamber Orchestra.
\end{abstract}

Keywords: Music Production, Virtual Concert, Digital Audio Workstation. 


\section{PENDAHULUAN}

Batavia Chamber Orchestra (BCO) adalah kelompok orkestra yang didirikan oleh dosen dan mahasiswa Prodi Pendidikan $\mathrm{Mu}-$ sik FBS UNJ pada 28 September 2014 yang menyelenggarakan konser tunggal tiap tahunnya. Namun, wabah pandemi yang melanda dunia sejak akhir 2019 mengakibatkan kegiatan pertunjukkan musik menjadi salah satu kegiatan yang dilarang karena sarat dengan kerumunan massa. Seiring berjalannya masa pandemi, para musisi melakukan pertunjukan musik secara virtual/daring (Septiyan, 2020). Sebagai contoh, adanya konser orkestra virtual dari Erwin Gutawa Orchestra, Jakarta City Philharmonic, Jakarta Concert Orchestra dan lain sebagainya. Konsep konser daring tersebut akhirnya dipilih $\mathrm{BCO}$ dalam penyelenggaraan konser tunggal tahunan, agar produktivitas dan eksistensi tetap terjaga tanpa risiko penularan covid-19.

Konser virtual adalah konsep baru yang tentunya memerlukan proses persiapan yang berbeda dengan persiapan konser secara luring/live. Salah satu perbedaannya adalah pemanfaatan teknologi untuk pengolahan audio, video, serta penayangannya. Karena karya yang dimainkan tidak ditampilkan secara live, permainan oleh pemain harus melalui proses rekam agar dapat dinikmati oleh penonton. Proses rekam audio dilakukan dengan memanfaatkan software Digital Audio Workstation/DAW. Digital Audio Workstation (DAW) adalah software yang menggantikan fungsi peralatan rekam audio/musik analog menggunakan menjadi rekam digital berbasis komputer (Andriyanto, 2020). Secara umum, DAW memiliki dua macam track, yaitu midi track dan audio track. Audio track digunakan untuk merekam suara vokal dan instrumen, seperti biola, drum, trumpet, bass dan lain sebagainya. Sedangkan pada midi track, sumber bunyi berasal dari VST instrument (virtual studio technology) melalui protokol data midi.
Dalam proses produksi audio konser BCO, software DAW yang digunakan adalah Logic Pro. Logic Pro adalah salah satu Digital Audio Workstation (DAW) dan MIDI sequencer untuk platform macOS Apple (Nahmani, 2015). Software ini dibuat pada awal 1990-an dan pada tahun 2002 dan mengganti nama menjadi Logic Pro. DAW Logic Pro tersedia melalui Mac App Store dengan harga 3.3 juta rupiah (per Agustus 2021). DAW ini merupakan DAW profesional/advanced yang eksklusif untuk digunakan pada produk laptop/komputer merk Apple (macbook/iMac).

DAW Logic Pro dipilih dalam proses produksi konser ini karena fasilitas yang dimiliki Prodi Pendidikan Musik UNJ adalah iMac yang menggunakan platform MacOS Apple dan sudah dilengkapi dengan DAW Logic Pro. Sumber daya tersebut digunakan pada perkuliahan komputerisasi musik, sehingga para mahasiwa (khususnya pemain BCO) sudah memiliki keterampilan untuk menggunakan DAW Logic Pro. Fitur profesional yang terdapat pada DAW Logic Pro mampu menunjang keseluruhan proses produksi musik. Tampilan user interface Logic Pro juga mudah digunakan (user friendly) dan memiliki harga yang relatif terjangkau.

Audio track direkam menggunakan microphone ataupun input audio menggunakan audio interface (soundcard eksternal) (Hardiman, 2020). Beberapa hal yang harus diperhatikan dalam merekam track audio adalah pengaturan tempo/musik guide, pemilihan jenis microphone yang tepat (microphone instrumen atau vokal, posisi dan jarak micropho$n e$, gain (gain structure), serta pengaturan kondisi ruangan yang kondusif dan tidak bising/noise. Untuk mendapatkan Midi Track, dapat menggunakan Fitur VST instrumen dari DAW Logic Pro. VST instrumen merupakan plugin yang dibuat untuk dapat berbunyi semirip mungkin dengan instrumen musik aslinya (Hardiman, 2020). Keunggulan dari midi track adalah data dapat diedit lebih leluasa, dapat di- 
ubah bunyi/suara VST instrumennya, dan lebih dapat meminimalisir biaya produksi musik (contoh : mampu mendapatkan bunyi timpani tanpa perlu membayar/menyewa alat ataupun pemain timpani aslinya).

Dengan menggunakan DAW, produksi karya musik dapat dilakukan dengan cepat serta dapat melalui proses editing, mixing, dan mastering untuk mendapatkan hasil yang optimal. Proses editing, sequencing, mixing, mentransfer, mengorganisasikan audio proyek rekaman antar sound engineer pun dapat dilakukan dengan mudah. Hal tersebut membuat biaya produksi dan distribusi musik bisa lebih terjangkau.

Proses Editing mencakup proses Gain staging dan balancing yang dilakukan pada audio track agar volume terdengar proporsional. Audio yang telah dilakukan gain staging dan balaning akan terasa lebih balance dan memiliki cukup headroom untuk dilakukannya tahap mixing selanjutnya. Trimming adalah memotong bagian audio kosong yang tidak diperlukan lalu dihilangkan untuk mengurangi noise yang mungkin muncul saat track kosong dibunyikan. Pitch correction adalah koreksi nada dari hasil rekam vokal ataupun instrumen karena secara natural tentunya terdapat nada-nada yang dimainkan kurang tepat saat perekaman (sering dikenal juga dengan istilah "fals"). Sering kali ditemui nada yang lebih tinggi atau lebih rendah beberapa cent dari seharusnya (jarak setengah nada $=100$ cent ). Disamping itu pitch correction juga dapat memperbaiki ritmik yang juga tidak persis akurat dengan grid tempo. Pitch corrector untuk dapat mengkoreksi nada contohnya plugin Melodyne (berbayar) ataupun fitur Flex Pitch yang disediakan dari DAW Logic Pro.

Proses mixing dan mastering dapat memberikan beberapa Treatment pada audio track seperti balancing seluruh track musik dengan mengutamakan kemunculan melodi utama (menggunakan automation), pengaturan kon- ten frekuensi (equalization), pengaturan dinamika (compressing), manipulasi panoramik posisi audio (panning), serta manipulasi efek ruang (reverb dan delay).

Dalam pembahasan akan diuraikan mengenai proses produksi konser dari tahap pra-produksi yang mencakup penentuan konsep, penampil, tema dan repertoire. Serta proses rekam audio, proses editing audio, proses mixing audio, serta proses mastering audio yang dilakukan hingga digabungkan dengan file video yang kemudian ditayangkan sebagai konser Virtual "Colourchestra" Batavia Chamber Orchestra.

Pengetahuan mengenai proses tersebut diharapakan dapat meningkatkan literasi digital dalam memproduksi karya musik yang relevan bagi pelaku seni pertunjukkan dan juga pendidikan musik abad-21. Digital literasi yang baik dapat meningkatkan potensi kerja karena kemampuan digital sudah dianggap sebagai keterampilan dasar yang diinginkan oleh banyak pencari kerja (Karpati, 2011). Konsep konser virtual pun berpotensi untuk terus berkembang meskipun pandemi telah usai.

\section{METODE}

Penulis melakukan penelitian menggunakan metode kualitatif untuk mendeskripsikan proses persiapan pada konser virtual BCO, terutama pada produksi audio. Adapun jenis pendekatan yang digunakan yakni pendekatan eksploratif dan studi dokumentasi.

\section{PEMBAHASAN}

\section{A. Tahap Penentuan Konsep, Penampil, Tema dan Repertoire (Pra-Produksi)}

Pada tahap ini ditentukan melalui rapat daring Pengurus $\mathrm{BCO}$ mengenai beberapa hal seperti konsep konser, tema yang akan diangkat, penampil dan karya-karya apa yang akan dibawakan. Konsep konser daring yang ditayangkan adalah tayangan audio-video yang sudah direkam sebelum penayangan- 


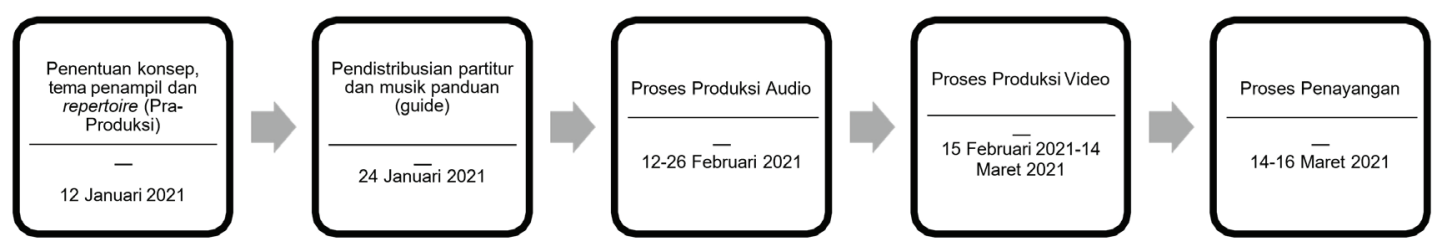

Skema 1. Proses produksi Konser Virtual "Colorchestra" Batavia Chamber Orchestra

nya. Berikut ini adalah rangkaian tahapan- tahapan proses produksi Konser Virtual "Colorchestra" Batavia Chamber Orchestra:

Tema yang diangkat adalah "Colorchestra", berasal dari perpaduan dua kata bahasa Inggris yaitu, color yang berarti warna dan orchestra yang berarti orkestra. Tema ini diangkat karena pada konser virtual $\mathrm{BCO}$ ini mengangkat berbagai lagu-lagu dari berbagai gaya/genre, serta nuansa penyajian yang berbeda-beda yang secara gagasan menggambarkan keragaman pada warna-warna musik orkestra. Genre musik yang diangkat pada konser diantaranya overture bernuansa musik klasikal, K-pop, Jazz, lagu wajib nasional hingga lagu anak. Kesemua genre tersebut dianggap terwakili oleh tema "Colorchestra". Partitur dibuat dengan software penulisan notasi musik, kemudian softcopy partitur dibagikan secara daring. Musik panduan yang diberikan berupa audio midi yang akan menjadi acuan tempo pada saat latihan mandiri dan proses produksi audio (rekam). Selain tempo, musik panduan juga membantu pemain dapat mendengar keseluruhan bagian lagu dan olahan aransemen/orkestrasi. Mengingat dimasa pandemi tidak memungkinkan untuk melakukan proses latihan seksional maupun gabungan yang membutuhkan kehadiran tatap muka seluruh pemain pada ruangan yang sama. Keseluruhan partitur dan musik panduan (music guide) sudah harus diserahkan kepada panitia konser sebelum tanggal 24 Januari 2021.

Konser disepakati untuk ditampilkan secara virtual/daring melalui platform digital loket.com karena pertimbangan link eksklusif yang akan didapatkan oleh setiap pembeli tiket. Tanggal 16 Maret 2021 dipilih menjadi tanggal tayangan perdana agar konser ini turut menjadi peringatan Hari Musik Nasional yang jatuh pada tanggal 9 Maret 2021. BCO juga melakukan kerjasama dengan WeCare. id untuk menyalurkan dana donasi yang didapat dari penjualan tiket. Wecare.id adalah organisasi yang menyalurkan bantuan di bidang kesehatan dan pendidikan. BCO mengalokasikan dana donasi untuk pembelian alat bantu dengar dan bantuan pembayaran operasi panggul untuk salah satu pasien anak yang terdata oleh Wecare.id.

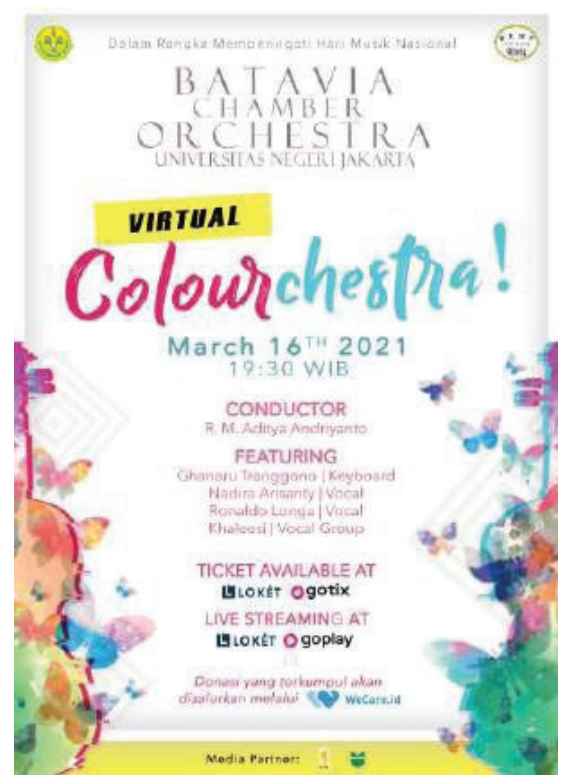

Gambar 1. Poster konser virtual "Colorchestra" Batavia Chamber Orchestra. (Sumber: Batavia Chamber Orchestra) 
Berdasarkan tema dan repertoire yang disepakati, ditentukan conductor (dalam hal ini selaku musik direktor), pemain-pemain orkestra serta penampil tamu yang terlibat didalam konser. Pemain orkestra yang dilibatkan dipilih berdasarkan seleksi yang dilakukan oleh pengurus $\mathrm{BCO}$ atas dasar kebutuhan instrumen pada repertoire. Keterlibatan penampil atas dasar izin orang tua/wali, kesediaan berpartisipasi dan kesediaan mematuhi protokol kesehatan yang ditetapkan. Adapun rincian jumlah penampil orkestra pada konser virtual "Colorchestra" adalah sebagai berikut:

Tabel 1. Rincian jumlah pemain Batavia Chamber Orchestra yang terlibat pada konser virtual "Colorchestra"

\begin{tabular}{|c|c|c|}
\hline No. & Instrumen & Jumlah penampil \\
\hline & Conductor & 1 orang \\
\hline \multicolumn{3}{|c|}{ Seksi Instrumen Gesek (28 Orang) } \\
\hline 1 & Violin 1 & 9 orang \\
\hline 2 & Violin 2 & 9 orang \\
\hline 3 & Viola & 2 orang \\
\hline 4 & Cello & 5 orang \\
\hline 5 & Contrabass & 2 orang \\
\hline
\end{tabular}

Seksi Instrumen Tiup Kayu dan Logam (15 orang)

\begin{tabular}{|c|l|l|}
\hline 6 & Flute & 3 orang \\
\hline 7 & Clarinet & 3 orang \\
\hline 8 & Saxophone Alto & 2 orang \\
\hline
\end{tabular}

\begin{tabular}{|c|l|l|}
\hline 9 & Saxophone Tenor & 1 orang \\
\hline 10 & Trumpet & 2 orang \\
\hline 11 & Horn & 2 orang \\
\hline 12 & Trombone & 2 orang \\
\hline \multicolumn{2}{|c|}{ Seksi Perkusi dan Combo (6 orang) } \\
\hline 13 & Perkusi & 2 orang \\
\hline 14 & Drum & 1 orang \\
\hline 15 & Keyboard/piano & 1 orang \\
\hline 16 & Guitar & 1 orang \\
\hline 17 & Bass elektrik & 1 orang \\
\hline \multicolumn{2}{|c|}{$\begin{array}{r}\text { Total Penampil Batavia } \\
\text { Chamber Orchestra }\end{array}$} & 50 orang \\
\hline
\end{tabular}

\section{B. Tahapan Proses Produksi Audio}

Setelah para pemain mempelajari secara mandiri partitur yang sudah diberikan, maka dilanjutkan dengan tahap proses produksi audio. Proses produksi audio dilakukan sebelum produksi video karena untuk perekaman video diperlukan audio asli hasil perekaman (bukan midi). Audio asli hasil rekaman dapat membuat para penampil, pemain dan vokalis dapat menghayati musiknya sehingga memperoleh ekspresi visual video yang baik dan gerakan yang sinkron. Tahapan produksi audio ini diawali dengan penentuan linimasa proses produksi audio yaitu rentang 12-26 Februari 2021.

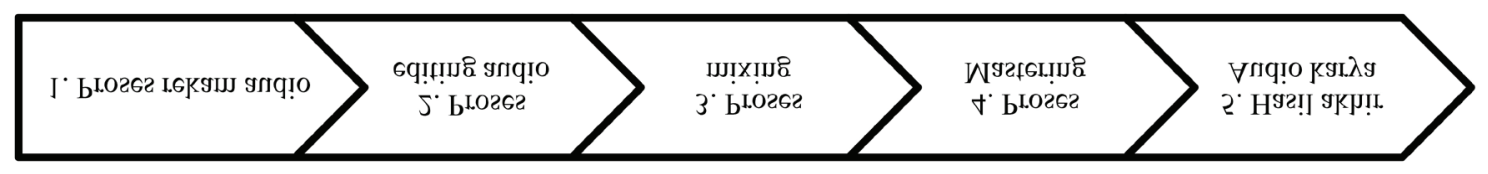

Skema 2. Tahapan Proses Produksi Audio Konser Virtual "Colorchestra" 
Tabel 2. Tahapan Proses Produksi Audio Konser Virtual "Colorchestra"

\begin{tabular}{|c|l|l|l|l|l|}
\hline No & \multicolumn{1}{|c|}{$\begin{array}{c}\text { Proses yang } \\
\text { Dilakukan }\end{array}$} & \multicolumn{1}{|c|}{$\begin{array}{c}\text { dilakukan } \\
\text { oleh }\end{array}$} & \multicolumn{1}{|c|}{$\begin{array}{c}\text { Tanggal } \\
\text { dilakukan }\end{array}$} & \multicolumn{1}{|c|}{ Perangkat Keras } & \multicolumn{1}{c|}{$\begin{array}{c}\text { Perangkat } \\
\text { Lunak }\end{array}$} \\
\hline 1. & Rekam Audio & $\begin{array}{l}\text { Tim Produksi } \\
\text { Audio }\end{array}$ & 12-14 Februari 2021 & $\begin{array}{l}\text { Laptop, PC, Mic Con- } \\
\text { denser, Audio Interface, } \\
\text { Speaker flat } \text { dan } \\
\text { Headphone }\end{array}$ & $\begin{array}{l}\text { DAW } \\
\text { Logic Pro }\end{array}$ \\
\hline 2. & Editing Audio & $\begin{array}{l}\text { Tim Produksi } \\
\text { Audio }\end{array}$ & 15-18 Februari 2021 & $\begin{array}{l}\text { Laptop, PC, Audio In- } \\
\text { terface, Speaker flat dan } \\
\text { Headphone }\end{array}$ & $\begin{array}{l}\text { DAW } \\
\text { Logic Pro }\end{array}$ \\
\hline 3. & Mixing Audio & R.M. Aditya & 19-23 Februari 2021 & $\begin{array}{l}\text { Laptop, PC, Audio In- } \\
\text { terface, Speaker flat } \text { dan } \\
\text { Headphone }\end{array}$ & $\begin{array}{l}\text { DAW } \\
\text { Logic Pro }\end{array}$ \\
\hline 4. & Mastering Audio & R.M. Aditya & 24-26 Februari 2021 & $\begin{array}{l}\text { Laptop, PC, Audio In- } \\
\text { terface, Speaker flat } \text { dan } \\
\text { Headphone }\end{array}$ & $\begin{array}{l}\text { DAW } \\
\text { Logic Pro }\end{array}$ \\
\hline
\end{tabular}

Tim produksi audio berjumlah 7 orang yang terdiri dari dosen, mahasiswa aktif dan alumni Prodi Pendidikan Musik UNJ. Tim produksi audio ini dibentuk agar proses rekam dan editing dapat dilakukan dengan lebih efektif dan efisien. Produksi audio dilakukan dengan merekam satu-persatu pemain orkestra yang berjumlah 50 orang beserta penampil tamu lain. Adapun strategi yang dilakukan adalah ruang rekam dibagi menjadi 4 ruangan, sehingga perekaman dapat dilakukan secara serentak. Keseluruhan proses produksi audio digarap pada software digital audio workstation Logic Pro.

DAW Logic Pro dipilih selain karena memiliki fitur yang lengkap, profesional, stabil dan mampu digunakan memproduksi karya musik ansambel besar, juga dikarenakan seluruh tim produksi audio yang merupakan mahasiswa prodi musik UNJ sudah dibekali pengetahuan dan keterampilan untuk mengoperasikan software DAW Logic Pro melalui mata kuliah Komputerisasi Musik.

\section{Proses Rekam Audio}

Pada proses rekam audio konser virtual "Colorchestra", untuk menghindari kerumunan, maka dilakukan dua macam metode pengumpulan data audio. Metode pertama pemain melakukan rekaman langsung di Prodi Pendidikan Musik (Gedung M Universitas Negeri Jakarta), dengan peralatan recording lengkap yang tersedia dikampus (terbagi menjadi 4 ruang rekam). Kondisi ruang rekaman di Gedung M UNJ sudah diberikan treatment peredam agar menyerupai studio rekaman profesional yang memiliki dinding kedap suara. Akustik ruangan tidak terlalu bergema (pantulan ruangan relatif sedikit), sehingga hasil rekaman dapat lebih jernih. Pemain yang diprioritaskan untuk melakukan rekaman dikampus adalah concert mistress (pemimpin orkestra BCO wanita), para prinsipal tiup dan gesek, penampil tamu, dan combo. Setiap pemain diberikan jadwal hari dan jam spesifik untuk bergantian rekam satu-persatu. Semua yang terlibat proses rekam dikampus wajib mematuhi protokol kesehatan yang ditetapkan, seperti selalu memakai masker, menjaga jarak, dan mencuci tangan. 


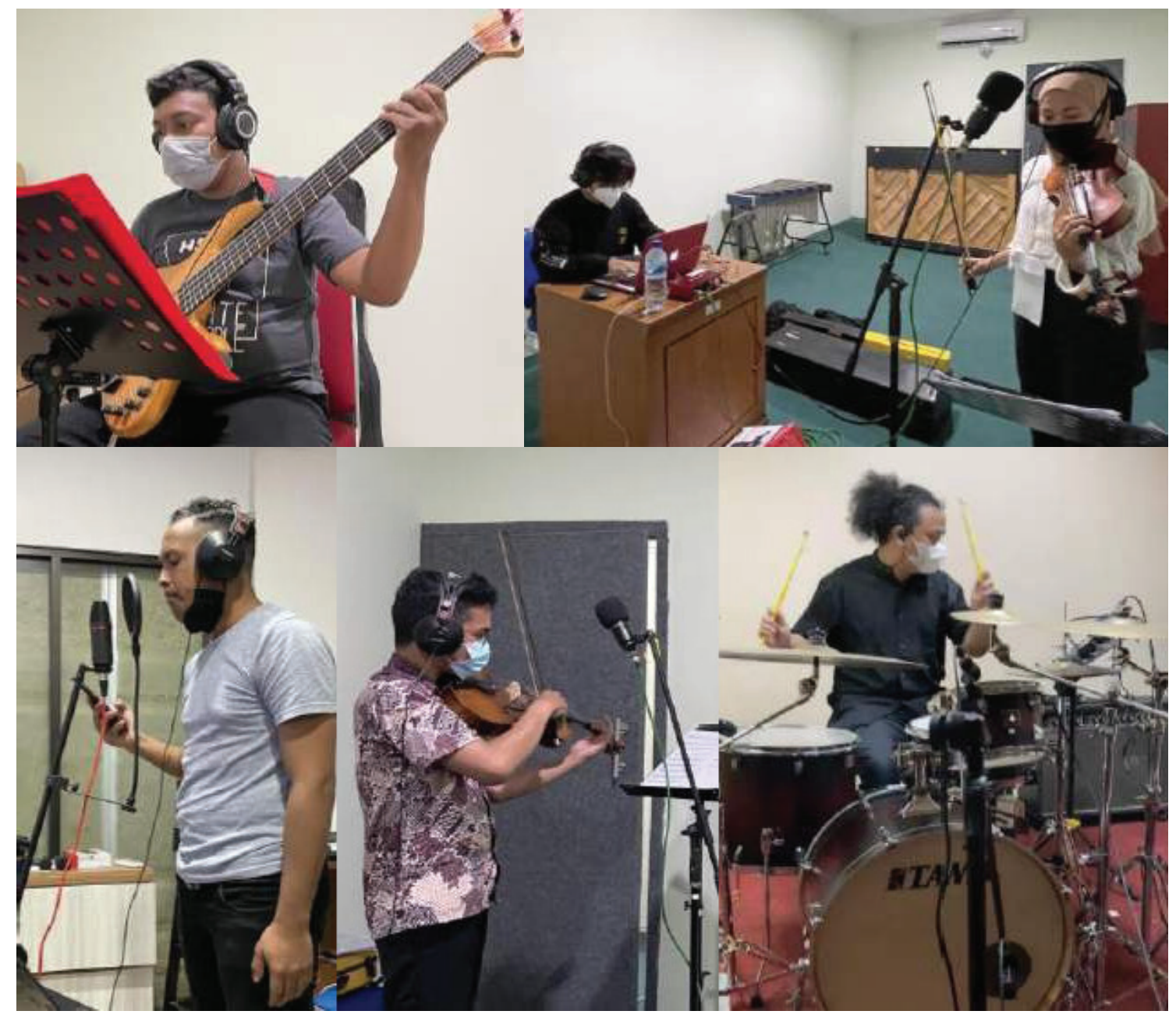

\section{Gambar 2. Proses Rekam Audio di Gedung M UNJ Tanggal 12-14 Februari 2021 (sumber: dokumentasi R.M. Aditya)}

Metode kedua adalah melakukan proses rekam mandiri dirumah masing-masing dengan smartphone ataupun alat rekam yang dimiliki masing-masing pemain. Panitia memberikan beberapa ketentuan dalam proses rekamannya agar hasil rekam audio memperoleh hasil yang optimal. Diantaranya ketentuan jarak instrumen dengan alat rekam, kondisi ruangan yang tidak bising (noise), format kualitas audio terbaik (high quality mp3 ataupun wav), hingga ketentuan batas waktu pengumpulan audio.
Perekaman track audio diawali pemilihan microphone, setelah itu melakukan pengaturan gain pada audio interface dan pengaturan posisi microphone ke instrumen/vokal. Lalu untuk mendengarkan playback musik guide digunakan headphone. Saat proses rekam, seandainya kurang sempurna ataupun terdapat kesalahan, maka dilakukan proses retake sampai mendapatkan hasil yang optimal. Proses retake dapat dilakukan hanya pada bagian tertentu, ataupun dari keseluruhan awal lagu. Ketika sudah selesai rekam, lalu 


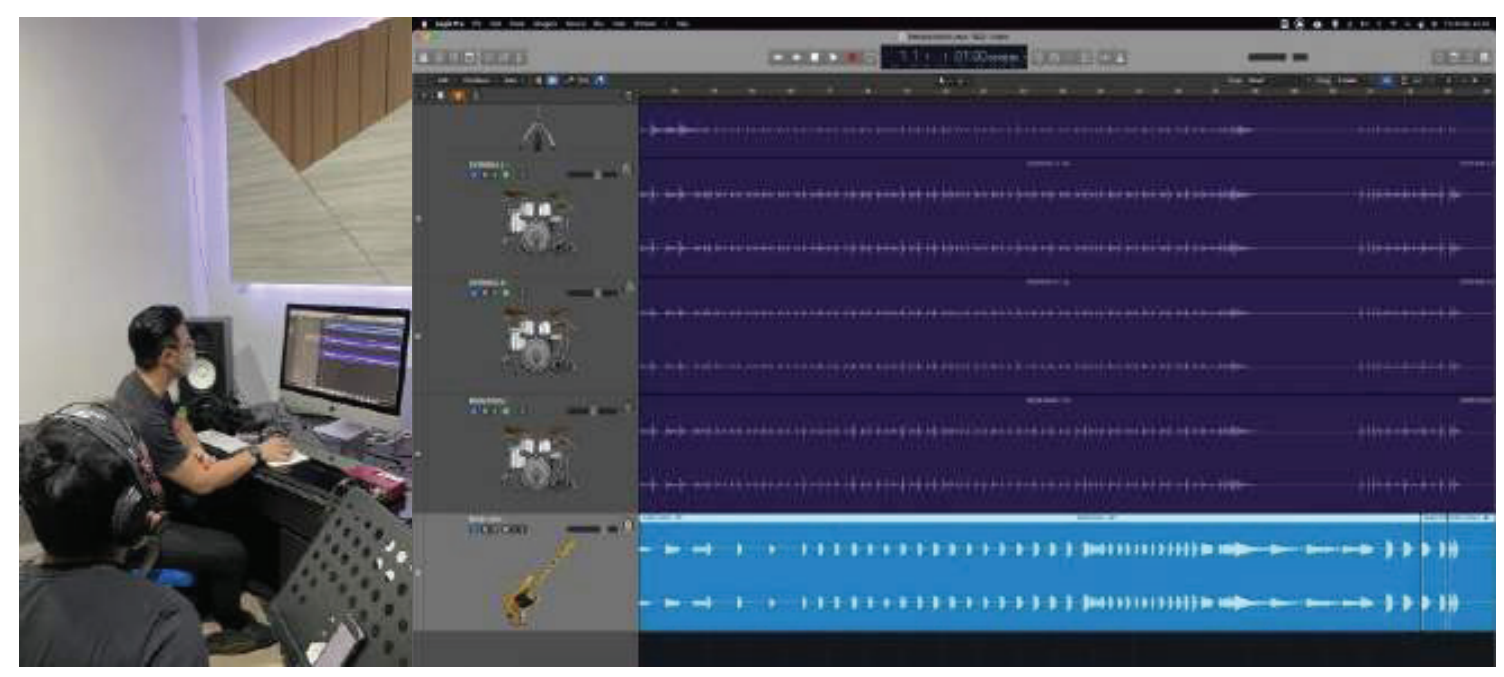

Gambar 3. Proses Rekam Audio Track Bass "Jivin in Jazz" menggunakan DAW Logic Pro (sumber: dokumentasi R.M. Aditya)

diperdengarkan kembali dari awal untuk memastikan tidak ada bagian yang perlu diperbaiki. Hasil rekam diperdengarkan menggunakan speaker flat, agar seluruh frekuensi pada track yang telah direkam dapat terpresentasikan dengan baik.

Pada proses rekam audio, terdapat beberapa track instrumen yang menggunakan bantuan midi track, contohnya instrumen timpani dan harpa. Hal ini dilakukan karena $\mathrm{BCO}$ dan UNJ tidak memiliki instrumen ter- sebut, sementara peminjaman instrumennya membutuhkan tambahan biaya dan kondisi pandemi membuat proses peminjaman daritempat lain menjadi cukup rumit. Pada konser virtual "Colorchestra", midi track timpani menggunakan VST Kontakt-Spitfire Hans Zimmer, salah satu VST yang pembuatannya menggunakan teknik sampling dari instrumen asli timpani, sehingga bunyi yang dihasilkan seperti layaknya rekam secara langsung track timpani.

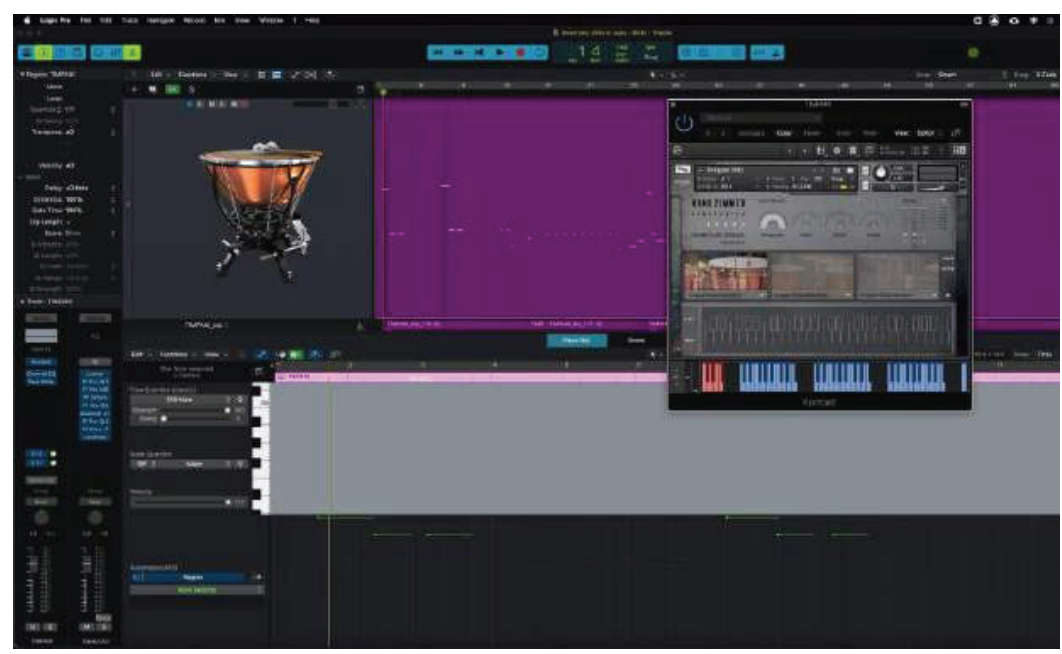

Gambar 4. Midi Track Timpani menggunakan VST Kontakt-Spitfire Hans Zimmer Percussion pada DAW Logic Pro (sumber: dokumentasi R.M. Aditya) 
Setelah dilakukan proses rekam selama 3 hari (12-14 Februari 2021), data audio dari 4 ruangan rekam digabungkan sesuai dengan judul lagu. Data audio tersebut digabungkan lagi dengan sumber data audio hasil perekaman mandiri yang dilakukan dirumah masing-masing. Dari hasil penggabungan kedua sumber tersebut, didapatkan total rata-rata 80 track tiap lagunya. Semua data yang terkumpul dijadikan satu pada DAW Logic Pro (terbagi menjadi 5 project lagu), untuk kemudian dilanjutkan pada proses editing audio.

\section{Proses Editing Audio}

Pada proses editing audio, terlebih dulu dilakukan proses gain staging dan balancing. Gain staging dilakukan agar masing-masing track memiliki gain yang kurang lebih sama pada kisaran 0 dBVU (diukur menggunakan VU meter). Selain itu dilakukan juga balancing, pengaturan agar volume masing-masing track sesuai dengan kebutuhan dari materi lagunya. Balancing dilakukan dengan cara mengatur level volume pada fader mixer, agar tiap track terdengar proporsional volumenya khususnya antara melodi utama utama maupun iringan. Dengan pengaturan gain dan balancing volume yang baik, membuat audio terasa lebih balance dan memiliki cukup headroom untuk dilakukannya tahap mixing selanjutnya.

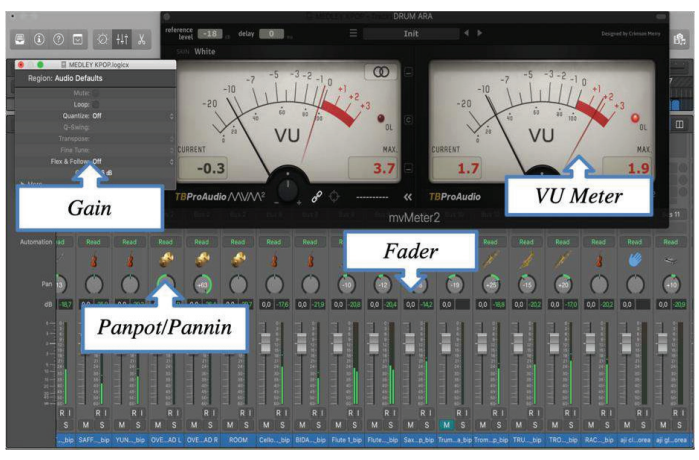

Gambar 5. Gain staging dan balancing pada DAW Logic Pro (sumber: dokumentasi

$$
\text { R.M. Aditya) }
$$

Pada proses editing dilakukan juga trimming, yaitu memotong bagian kosong pada track audio yang tidak diperlukan. Hal ini dilakukan supaya mengurangi noise (bunyi AC, atau kebocoran audio lainnya) yang mungkin muncul saat track kosong dibunyikan. Dengan trimming ini memastikan bagian audio mana yang benar-benar ingin digunakan pada lagu, membuat audio lebih bersih.

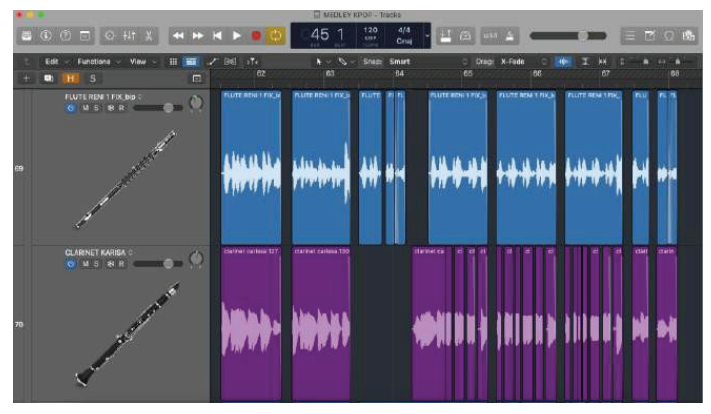

Gambar 6. Trimming track flute dan clarinet pada $D A W$ Logic Pro (sumber: dokumentasi R.M. Aditya)

Proses editing selanjutnya adalah koreksi nada (pitch correction), untuk memperbaiki tinggi nada dan ritmik. Apabila hal ini tidak dikoreksi tentu akan membuat harmonisasi musik terasa tidak rapi, ritmik terasa tidak kompak dan akan mengganggu fokus dari pendengar. Pitch corrector untuk mengkoreksi nada contohnya plugin Melodyne (berbayar) ataupun fitur Flex Pitch yang disediakan dari DAW Logic Pro. Baik Melodyne maupun Flex Pitch ini dapat digunakan untuk mengkoreksi ritmik juga dengan cara menggeser ke kanan ataupun kekiri data audio. Koreksi dilakukan dengan ketelitian dan kehati-hatian agar tidak berlebihan dan tetap terasa alami/manusiawi. 


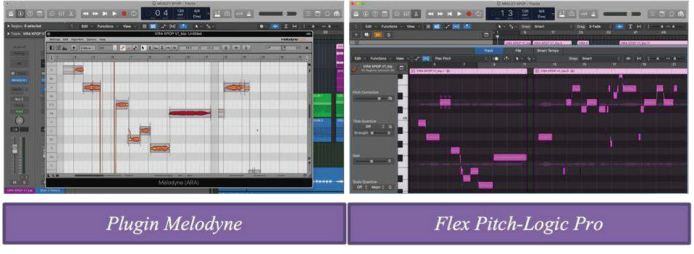

Gambar 7. Penggunaan Plugin Melodyne dan Flex Pitch pada DAW Logic Pro (sumber: dokumentasi R.M. Aditya)

Dilakukan juga editing pada midi track berupa edit data, balancing, trimming, juga dilakukan quantization (merapikan data midi sesuai nilai not/ketukan), note editor (menggeser/merubah/menghapus/menambahkan not), velocity editor (merubah dinamika tiap not), mengatur level volume pada fader mixer, agar tiap track midi terdengar proporsional volumenya antara track midi dengan track audio instrumen orkestra lainnya.

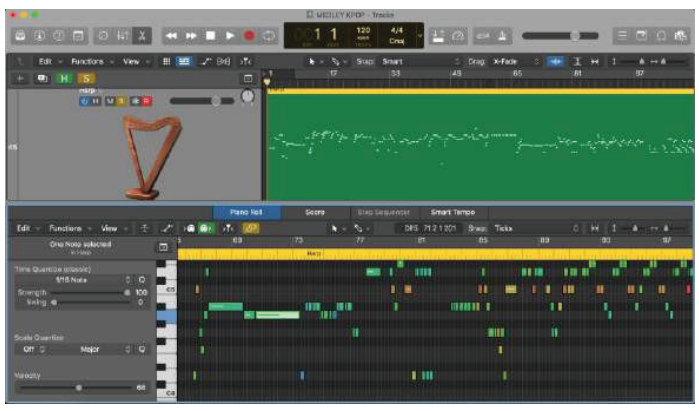

Gambar 8. Editing data midi VST instrumen harpa pada $D A W$ Logic Pro (sumber: dokumentasi R.M. Aditya)

\section{Proses Mixing Audio}

Proses lanjutan dalam produksi karya musik konser virtual "Colorchestra" Batavia Chamber Orchestra adalah proses mixing. Pada konser virtual ini proses mixing dan mastering digarap langsung oleh penulis selaku konduktor, arranger dan orkestrator. Pada hakikatnya, seorang konduktor bertugas memimpin dan mengarahkan pemain agar dapat memberikan sajian karya musik dengan sebaik-baiknya kepada audiens. Di masa pandemi, salah satu cara untuk tetap menjalankan tugas tersebut adalah dengan mengarahkan serta memadukan musik secara digital dalam proses mixing dan mastering.

Proses mixing dilakukan dengan mengkombinasikan seluruh track audio dan midi pada tiap project pada DAW dengan beberapa treatment kreatif dan estetis. Treatment tersebut diantaranya berupa balancing seluruh track musik dengan mengutamakan kemunculan melodi utama (menggunakan automation), pengaturan konten frekuensi (equalization), pengaturan dinamika (compressing), manipulasi panoramik posisi audio (panning), serta manipulasi efek ruang (reverb dan delay). Treatment ini diberikan agar memperoleh hasil akhir mixing yang layak diperdengarkan kepada para pendengar.

\begin{tabular}{|l|l|l|l|l|}
\hline $\begin{array}{l}\text { Balancing } \\
\text { - Mengatu } \\
\text { rVolume } \\
\text { (melodi } \\
\text { utama) } \\
\text { - Automatio }\end{array}$ & $\begin{array}{l}\text { Equalization } \\
\text { - Pengaturan } \\
\text { Frekuensi } \\
\text { tiap track } \\
\text { - Tonal }\end{array}$ & $\begin{array}{l}\text { Dynamic } \\
\text { - Pengaturan } \\
\text { Compressor } \\
\text { - Penentuan } \\
\text { rasio }\end{array}$ & $\begin{array}{l}\text { Peverb- } \\
\text { Delay }\end{array}$ \\
\end{tabular}

Skema 3. Proses mixing pada konser virtual "Colorchestra" (Sumber: dokumentasi R.M. Aditya) 


\section{a. Balancing-Automation}

Proses balancing dilakukan dengan menggunakan fitur automation. Balancing membuat melodi utama dan tekstur serta dinamika yang variatif sesuai aransemen dan komposisi karya dapat terbentuk dengan baik. Volume automation juga dilakukan pada seluruh track dari karya-karya yang dibawakan dengan tetap memperhatikan full score partitur orkestra. Otomasi volume (dalam satuan $\mathrm{dB}$ ) dilakukan menyesuaikan perpindahan melodi utama. Sehingga musik yang dihasilkan mengedepankan melodi utama, lebih dinamis, estetis dan natural layaknya sebuah orkestra yang diarahkan dinamikanya secara langsung oleh seorang konduktor.

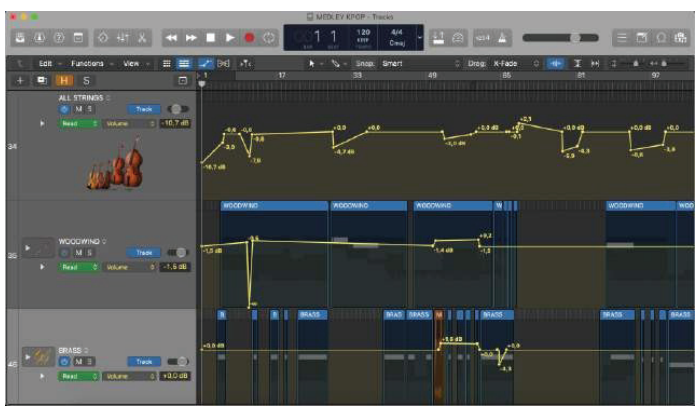

Gambar 9. Volume automation seksi gesek dan tiup pada $D A W$ Logic Pro (sumber: dokumentasi R.M. Aditya)

b. Pengaturan Konten Frekuensi (Equalization)

Pengaturan konten frekuensi pada proses mixing dilakukan pada tiap-tiap track menggunakan VST effect berupa equalizer (EQ). Equalizer digunakan untuk menguatkan maupun mengurangi intensitas energi pada frekuensi sinyal audio tertentu. Hasil akhir yang diperoleh adalah tonal balance yang baik pada keseluruhan frekuensi lagu, dimana antara frekuensi rendah (low), tengah (middle) dan tinggi (high) tidak bertumpuk dan proporsional.

Karakter frekuensi instrumen yang didapatkan dari hasil rekaman sangat heterogen.
Sesama track instrumen gesek sekalipun, kualitas kayu, resonansi, bow, senar dan teknik bermain mempengaruhi bunyi yang dihasilkan, terlebih bila saat perekaman individu menggunakan microphone dan kondisi ruangan yang berbeda satu sama lain. Maka, pada proses mixing dilakukan pengaturan frekuensi. Equalizer digunakan hingga terbentuk sonoritas antar track instrumen gesek lebih baik dan terasa menyatu.

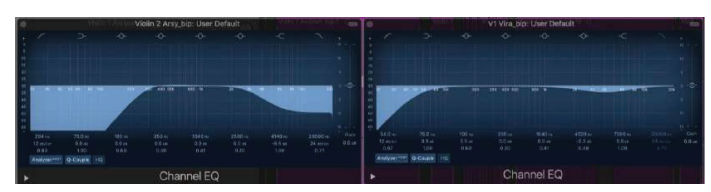

Gambar 10. Perbedaan pengaturan equalizer pada 2 track violin yang berbeda.

(Sumber: dokumentasi R.M. Aditya)

Selain itu, Equalizer juga digunakan untuk koreksi hasil perekaman yang tidak ideal. Contohnya saat pemain biola yang melakukan perekaman dirumah yang letak rumahnya dipinggir jalan, tentunya akan berdampak pada terekamnya low frekuensi yang bukan dihasilkan dari instrumen biola yang dimainkannya. Frekuensi low tersebut di low cut (dipotong) menggunakan equalizer. Fungsi enhancive equalizer juga diterapkan pada file perekaman yang sudah baik, agar ditingkatkan lagi kualitas maupun karakternya. Karakter frekuensi dari instrumen disesuaikan dengan kebutuhan.

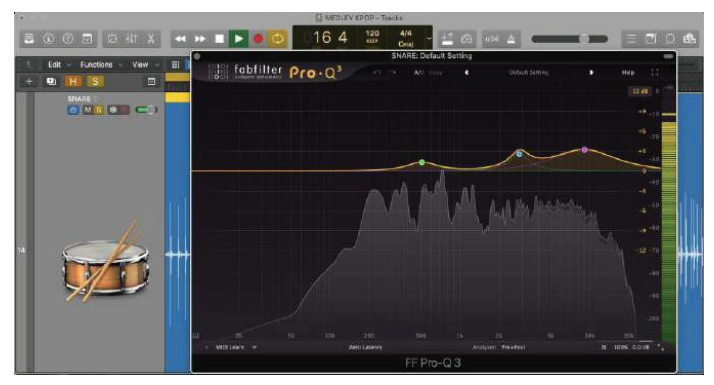

Gambar 11. Contoh fungsi enhancive $E Q$ pada track snare drum. (Sumber: dokumentasi R.M. Aditya) 
c. Pengaturan Dinamika (Compressing)

Proses mixing berikutnya adalah pengaturan dinamika dengan memberi VST plugin compressor. Hasil rekaman vokalis maupun instrumen memiliki dinamika yang berbeda-beda sepanjang lagu, terkadang lembut terkadang keras, bahkan terkadang lompatan dinamika yang terjadi terlalu kontras. Plugin compressor membatasi rentang dinamika antara bagian lembut dengan keras, membuatnya lebih konstan dan konsisten, agar pendengar lebih nyaman saat mendengarkan hasil akhir karya musik. Pengaturan compressor yang digunakan selalu diawali dengan kompresi rendah, seperti pada rasio 2:1 hingga 5:1, lalu menurunkan threshold secara perlahan hingga memperoleh pengurangan gain (gain reduction) kisaran 3 hingga $5 \mathrm{~dB}$. Hal tersebut dilakukan untuk mencegah hilangnya dinamika bunyi/suara dari sebuah karya musik, yang dapat membuat musik terasa tidak bernyawa dan membosankan

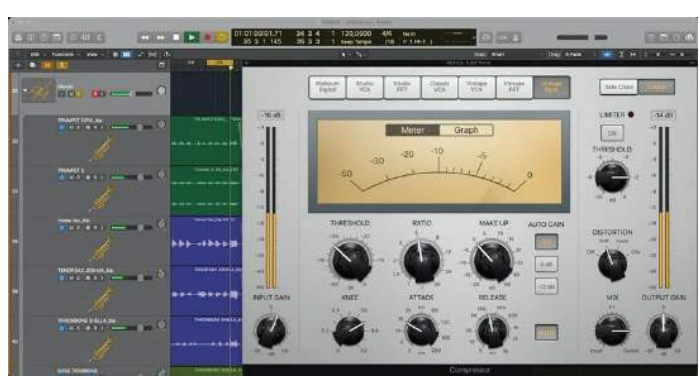

Gambar 12. Penggunaan compressor track tiup logam (brass) pada $D A W$ Logic Pro. (Sumber: dokumentasi R.M. Aditya)

\section{d. Pengaturan Panorama Bunyi (Panning)}

Pada proses mixing dilakukan juga pengaturan panorama bunyi atau LCR Panning (left, Center, Right Panning). Tiap track yang telah digabungkan awalnya terdengar ditengah, lalu dilakukan panning untuk dimanipulasi panoramanya. Panning setiap karya dibuat konsisten dengan pengaturan $L C R$ panning yang kurang lebih sama pada tiap panorama bunyi instrumen orkestranya.

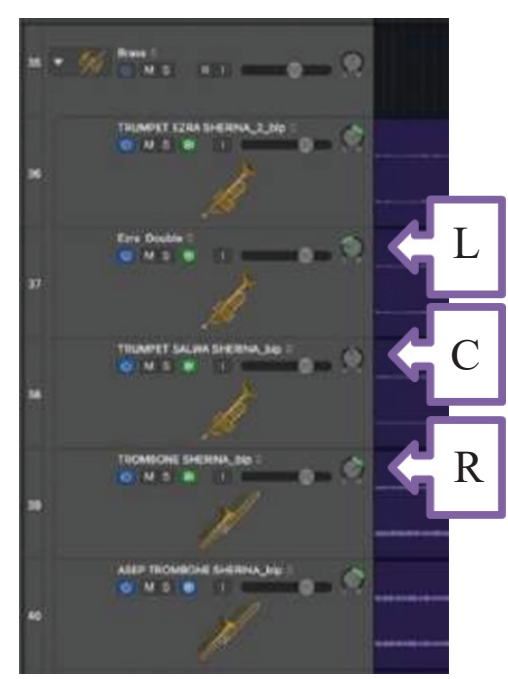

\section{Gambar 13. LCR Panning track tiup lo- gam (brass) pada DAW Logic Pro. (Sum- ber: dokumentasi R.M. Aditya}

Pada karya lagu "Medley Petualangan Sherina" yang terdapat penampil tamu yang terlibat pengisi vokal adalah Khaleesi yang merupakan vokal grup dan Aldo Longavokalis pria, LCR panning diatur menggunakan automation. Saat vokalis menyanyikan melodi utama, akan secara otomatis menjadi diposisi tengah (center). Bila sedang berperan sebagai backing, maka diposisikan di kanan ataupun kiri. Hal ini membuat audio vokal terasa dinamis, lebar, dengan memprioritaskan melodi utama lagu tetap fokus berada ditengah.

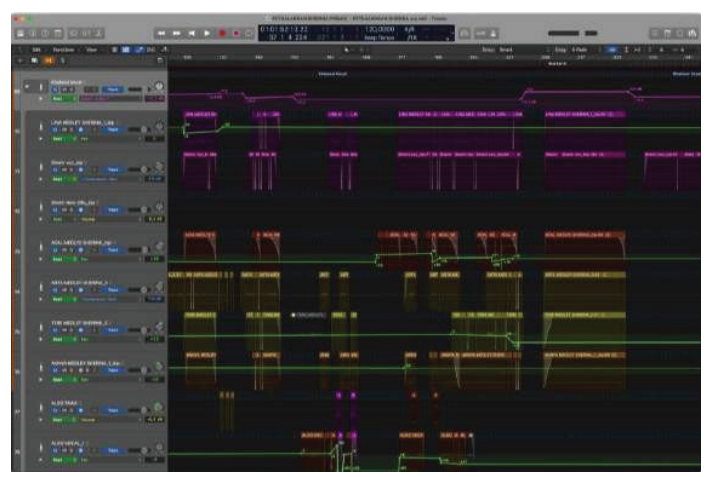

Gambar 14. Automation Panning pada track grup vokal. (Sumber: dokumentasi R.M. Aditya) 
e. Pengaturan Efek Ruang (Reverb-Delay)

Tahap selanjutnya dari proses mixing konser virtual "Colorchestra" adalah memberikan efek ruang, diantaranya reverb dan delay. Reverb yang digunakan ada 2 macam, reverb berdurasi pendek layaknya sebuah ruangan kecil dan reverb berdurasi panjang layaknya pada sebuah concert hall besar. Reverb berdurasi pendek lebih banyak digunakan untuk track vo$\mathrm{kal} /$ instrumen yang ingin terasa didepan, menjadi fokus ataupun pemegang melodi utama. Sementara reverb berdurasi panjang diperlukan untuk ambience musiknya, memperlebar stereo image, mendapatkan karakter konser pada ruangan konser besar dan memanipulasi instrumen pada dimensi posisi belakang. Perpaduan kedua reverb akan membuat pendengar merasa seperti mendengar sebuah konser orkestra diruangan besar yang megah. Pemberian efek ruang reverb mempengaruhi nuansa keseluruhan dengan membentuk dimensi kedalaman tiap-tiap track instrumen dan memanipulasi bunyi layaknya berada pada ruang yang memberi pantulan bunyi.

Sementara penggunaan efek delay (sering dikenal dengan echo) diatur dengan otomasi, hanya pada solois vokal atau instrumen tertentu. Delay diatur pada not $1 / 8$ ataupun $1 / 8$ triplet dengan tempo yang sama. Penggunaan efek ruang ini ditempatkan pada send effect DAW Logic Pro, agar setiap track dapat menggunakan pengaturan efek ruang yang sama.

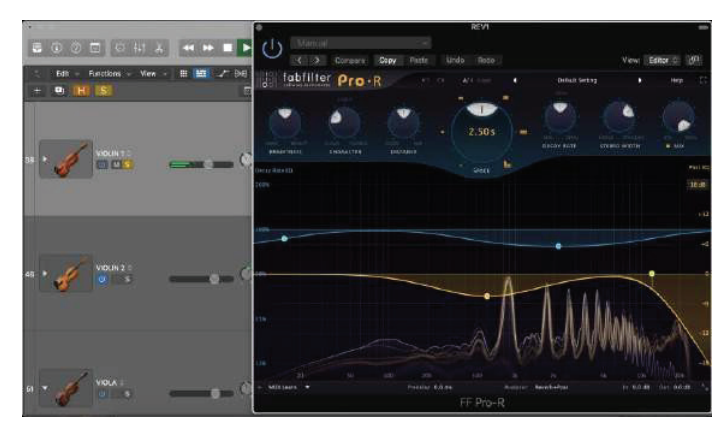

Gambar 15. Penggunaan plugin reverb fabfilter pada $D A W$ Logic Pro. (Sumber: dokumentasi R.M. Aditya)

\section{Proses Mastering Audio}

Setelah melakukan rangkaian proses mixing pada tiap-tiap track, langkah selanjutnya adalah pre mastering, yaitu mempersiapkan audio dengan kondisi yang baik agar dapat memasuki proses mastering. Pre Mastering memastikan semua track sudah ditreatment sesuai kebutuhan, tidak ada yang clipping, bersih dan audio pada master volume berada dibawah -6dB agar masih memiliki headroom untuk dilakukan proses mastering. Setelah itu, audio di-bounce (mixdown) untuk kemudian dilanjutkan ke proses mastering dengan format audio Wave 24 bit $48 \mathrm{kHz}$.

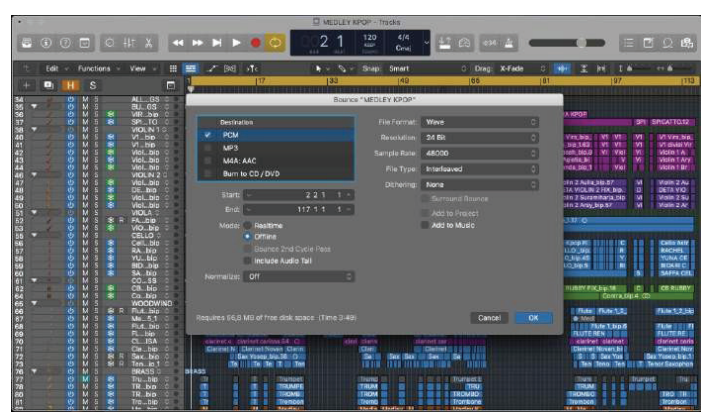

Gambar 16. Bounce pre-mastering project karya pada $D A W$ Logic Pro. (Sumber: dokumentasi R.M. Aditya)

Data bounce dari proses mixing hingga pre-mastering kemudian memasuki tahap mastering yang merupakan proses akhir mempersiapkan audio agar layak beredar/ publikasi dengan kualitas yang baik. Perangkat yang digunakan adalah perangkat komputer (Apple iMac), audio interface dan speaker flat. Dilakukan pengaturan Tonal balance frekuensi dan tingkat kekerasan audio (loudness) agar konsisten saat dibunyikan diberbagai perangkat speaker/pengeras suara. Proses mastering juga digarap langsung oleh penulis selaku konduktor BCO untuk memastikan kelayakan hasil akhir orkestra yang akan didengar oleh audiens. Proses mastering menggunakan beberapa VST plugin effect pihak ketiga dari Fabfilter, iZotope dan Voxengo. 
Berikut ini adalah rantai proses mastering (mastering chain) yang dilakukan berurutan pada master stereo out:

a. Pre-EQ menggunakan Fabfilter Pro-Q3

b. Dynamic (multiband compressor) menggunakan Fabfilter Pro-MB

c. Saturasi menggunakan Fabfilter Saturn

d. De-esser menggunakan Fabfilter Pro-DS

e. Pre-limiter menggunakan Fabfilter Pro-L2

f. Post-EQ menggunakan Fabfilter Pro-Q3

g. Stereo-imaging menggunakan iZotope Ozone imager 2

h. Post-limiter menggunakan Fabfilter Pro-L2

i. Monitoring menggunakan Voxengo SPAN
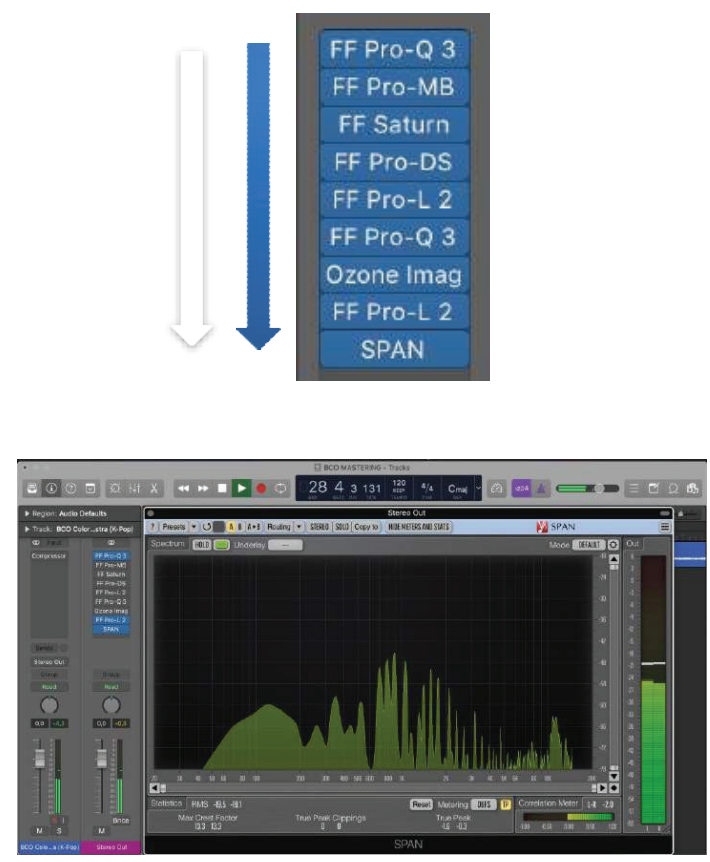

Gambar 17. Mastering chain pada stereo out dan Plugin Voxengo Span pada $D A W$ Logic Pro. (Sumber: dokumentasi R.M. Aditya)

a. Pengaturan Pre-EQ Menggunakan Fabfilter Pro-Q3

Konsep pengaturan konten frekuensi (equalization) pada tahap mastering (pre ma- upun post $E Q$ ) dilakukan untuk mencapai tonal balance yang diinginkan. Pada tahap mastering penambahan maupun pengurangan frekuensi tidak dilakukan dalam kuantitas besar/ekstrim. Pengaturan EQ pada mastering biasanya berkisar maksimal $2 \mathrm{~dB}$ (penambahan ataupun pengurangan).

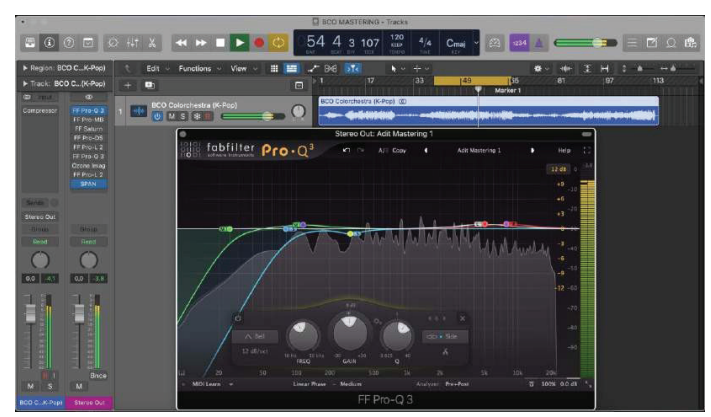

Gambar 18. Mastering chain Pre-EQ menggunakan Fabfilter Pro-Q3. (Sumber: dokumentasi R.M. Aditya)

Pada contoh di atas, pengaturan pada pre$E Q$, diawali dengan low cut pada mid-side. Mid-side sendiri merupakan pemrosesan untuk memisahkan audio tengah (mid) dan audio samping (side) dengan tujuan agar musiknya dapat terasa lebih stereo, lebar dan megah. Pada mid dilakukan pemotongan frekuensi low di $25 \mathrm{~Hz}$ (low cut), mengingat frekuensi low dibawah $25 \mathrm{~Hz}$ tidak diperlukan. Sementara untuk side, dilakukan pemotongan pada $80 \mathrm{~Hz}$ agar frekuensi low dibawah $80 \mathrm{~Hz}$ hanya terfokus di tengah/mid saja. Selain itu pada side juga dilakukan pembeda antara sisi kanan dan kiri agar terasa lebih dinamis dan stereo.

b. Pengaturan Dinamika Menggunakan
Fabfilter Pro-MB
Setelah Pre-EQ, selanjutnya dilakukan pengaturan dinamika keseluruhan musik menggunakan multiband compressor 4 band dari Fabfilter, dengan pembagian wilayah low, mid low, mid high dan high. Pada masing-masing wilayah band dilakukan pengaturan kompresi yang berbeda satu sama lain. 
Pengaturan dinamika (compressor) dilakukan dengan kompresi yang rendah. Multiband compressor pada tahap mastering diterapkan spesifik pada wilayah frekuensi tertentu tanpa merubah wilayah frekuensi lainnya dan diterapkan untuk keseluruhan hasil mixing sebelumnya, bukan pada setiap track seperti pada proses mixing. Pengaturan multiband compressor digunakan dengan hatihati dan bijak, agar dinamika dari karya tidak hilang.

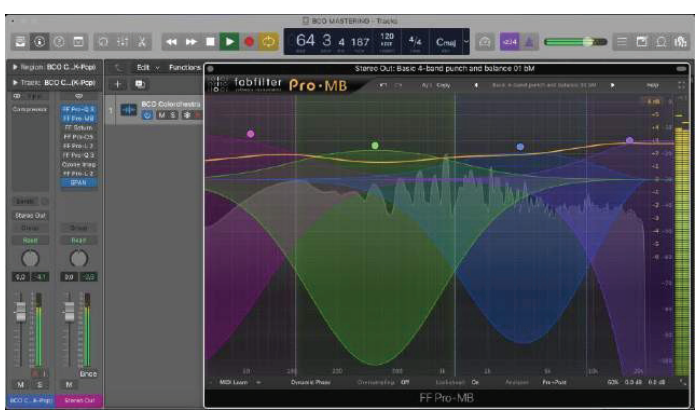

Gambar 19. 4 band multiband compressor menggunakan Fabfilter Pro-MB. (Sumber: dokumentasi R.M. Aditya)

c. Pengaturan Saturasi Menggunakan Fabfilter Saturn

Saturasi diberikan untuk memperoleh karakter musik yang lebih tebal dan berkarakter. Pada Fabfilter Saturn digunakan emulasi saturasi yang tabung (tube saturation) untuk mendapatkan harmonik series dengan area frekuensi middle yang agak terdistorsi namun tetap musikal dan frekuensi high yang lebih cemerlang. Sama halnya dengan multiband compressor, saturasi yang digunakan terbagi menjadi 4 band/wilayah frekuensi, yaitu pembagian wilayah low, mid low, mid high dan high.

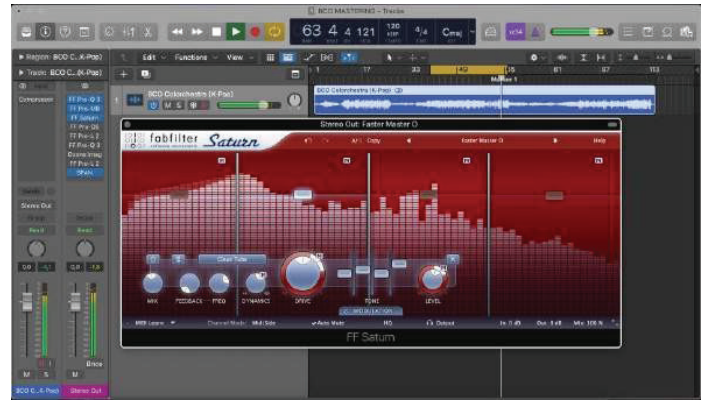

Gambar 20. Saturasi tabung menggunakan Fabfilter Saturn. (Sumber: dokumentasi R.M. Aditya)

d. Pengaturan De-esser Menggunakan Fabfilter Pro-DS

De-esser digunakan untuk membatasi frekuensi tinggi yang ditimbulkan dari akumulasi frekuensi tinggi dari seluruh track (contohnya frekuensi tinggi cymbal drum, violin, trumpet, flute dan sebagainya). De-esser digunakan menyerupai limiter namun khusus untuk frekuensi tinggi.

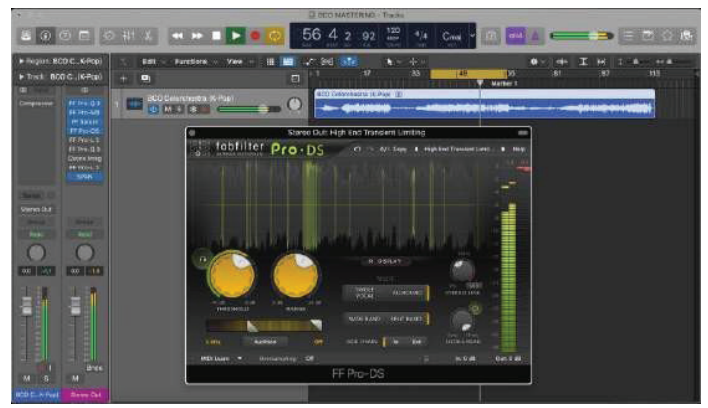

Gambar 21. De-esser menggunakan Fabfilter Saturn. (Sumber: dokumentasi R.M. Aditya)

e. Pengaturan Pre-limiter Menggunakan Fabfilter Pro-L2

Pre-limiter digunakan sebagai limiter tahap awal untuk menaikkan gain dan membatasi sinyal audio dalam skala yang tidak ekstrim. Hal ini membantu kerja limiter yang bila hanya diberikan diakhir (1 limiter), maka limiter akan bekerja lebih berat. Keuntungan lain bila menggunakan double limiter, akan 
mendapatkan karakter hasil akhir musik yang lebih tebal.

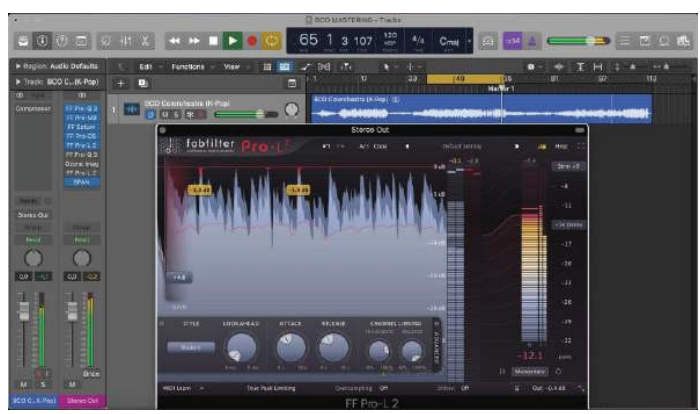

Gambar 22. Pre-limiter menggunakan

Fabfilter Pro-L2. (Sumber: dokumentasi

\section{R.M. Aditya)}

f. Pengaturan Post-EQ Menggunakan Fabfilter Pro-Q3

Pengaturan EQ pada tahap ini lebih bersifat korektif, dengan tujuan mengkompensasi ataupun mengurangi frekuensi berlebihan yang mengganggu. Tujuannya adalah memastikan keseluruhan musik memiliki tonal balance yang baik. Post-EQ digunakan untuk mengurangi area mid high yang berlebihan dan membatasi area sub-low $25 \mathrm{~Hz}$ kebawah (low cut).

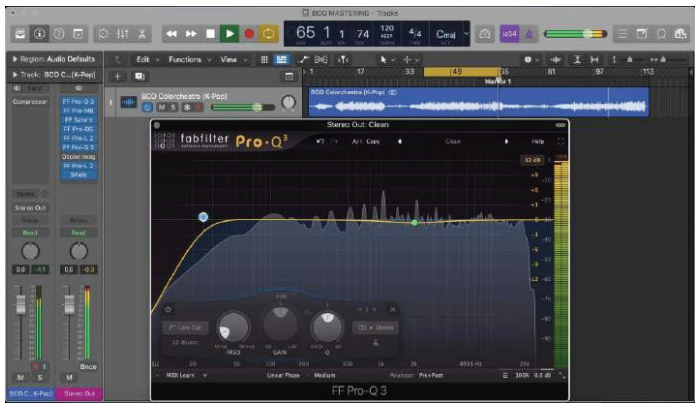

Gambar 23. Post-EQ menggunakan Fabfilter Pro-Q3. (Sumber: dokumentasi R.M. Aditya)

g. Pengaturan Stereo-imaging Menggunakan iZotope Ozone imager 2

Tahap mastering selanjutnya adalah pengaturan stereo-imaging, untuk memperoleh hasil akhir estetis audio yang terasa lebar (wide), sehingga pendengar merasa sedang mendengarkan dari panggung musik ataupun gedung konser yang lebar dan luas. Stereo-imaging merupakan perluasan manipulasi spasial dari proses panning yang sudah dilakukan sebelumnya pada tahap mixing. Penambahan kelebaran (stereo- width) yang dilakukan sebesar $30 \%$ pada plugin iZotope Ozone imager 2. Dari pengaturan ini, separasi semakin jelas antara mid dan side dari preEQ sebelumnya. Musik terasa lebih lebar dan tebal. Untuk perbandingan saat proses stereo ini, audio dibandingkan juga dengan versi mono (menggunakan bypass)

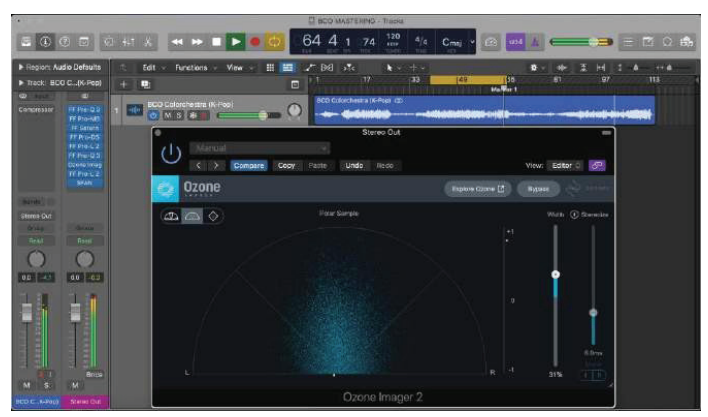

Gambar 24. Stereo-imaging menggunakan iZotope Ozone imager 2. (Sumber: dokumentasi R.M. Aditya)

h. Pengaturan Post-limiter Menggunakan Fabfilter Pro-L2

Tahap Post-Limiter adalah finalisasi tingkat kekerasan bunyi lagu (loudness) menggunakan limiter/maximizer. Pada tahap ini limiter menaikkan tingkat kekerasan bunyi keseluruhan musik tanpa resiko clipping/peak (bunyi/suara terdengar pecah). Plugin limiter mampu mengoptimalkan tingkat kekerasan lagu (loudness). Tingkat kekerasan tiap karya lagu pada konser virtual "Colorchestra" ratarata pada -11 hingga -12 LUFS (Loudness Unit Full Scale). Setelah melalui post-limiter maka lagu kembali di-bounce (mixdown) dalam format audio Wave pada 24 bit $48 \mathrm{kHz}$. 


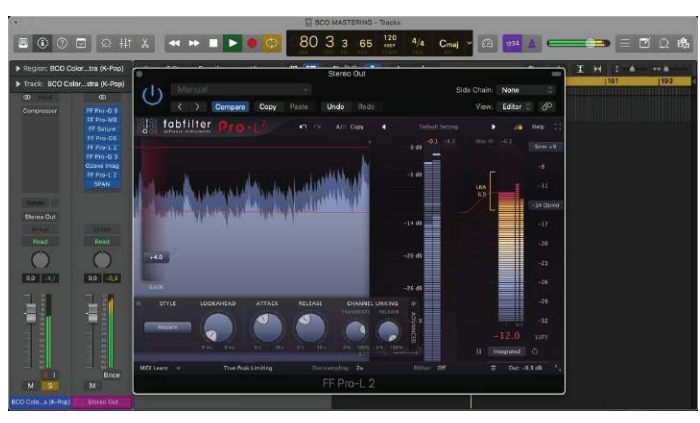

Gambar 25. Post-limiter menggunakan Fabfilter Pro-L2. (Sumber: dokumentasi R.M. Aditya)

Sebelum diserahkan kepada tim editor video, hasil mastering diperdengarkan pada beberapa perangkat pengeras suara, seperti headphone, speaker flat, speaker bluetooth, sampai speaker audio didalam mobil. Hal ini dilakukan untuk mengecek hasil mastering apakah sudah konsisten dan terdengar enak bila dibunyikan pada speaker yang berbeda. Selain itu audio tersebut juga disebar kebeberapa pemain orkestra agar dapat memberi opini, masukan dan saran terkait hasil mixing dan mastering yang dilakukan. Setelah beberapa perbaikan dilakukan, audio dikirim ke tim produksi video untuk digabungkan dengan video konser virtual "Colorchestra" Batavia Chamber Orchestra.

\section{Proses Produksi Video}

Tim produksi video dipimpin oleh Robby Suharlim, yang merupakan alumni dari Prodi Pendidikan Musik, melakukan pengambilan video di Gedung M Kampus A Universitas Negeri Jakarta. Video direkam menggunakan peralatan kamera DSLR, lampu dan latar hijau green screen. Latar green screen diperlukan agar dapat diedit menjadi berbagai warna latar, menyesuaikan dengan nuansa lagu yang dibawakan. Proses rekam video mulai dilakukan pada tanggal 16 Februari 2021 selama 2 hari dengan protokol kesehatan yang ditetapkan.

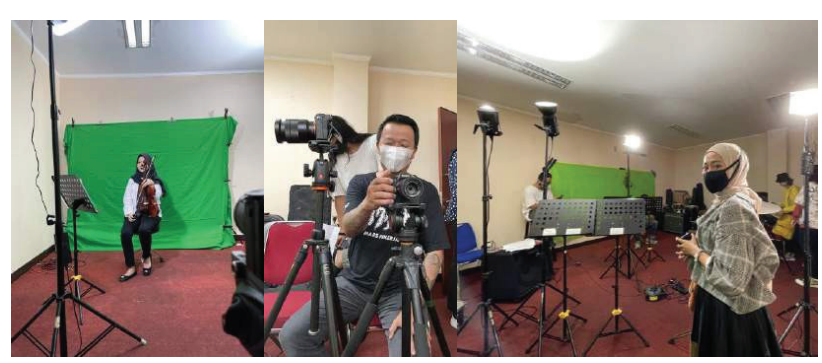

\section{Gambar 26. Proses Rekam Video Konser Virtual "Colorchestra". (Sumber: doku- mentasi R.M. Aditya)}

Kemudian tim video melakukan proses editing dan penyatuan setiap aset video konser virtual "Colorchestra" yang direkam langsung oleh tim video maupun dari rumah masing- masing pemain. Sama halnya dengan audio, hasil video yang sudah diedit dibagikan ke panitia untuk dilakukan revisi. Tujuannya untuk memastikan setiap video sesuai dengan nuansa tema lagu dengan penyatuan yang baik dan sinkron dengan musik hasil dari produksi audio sebelumnya. Saat tahap revisi sudah selesai, dilakukan uji tayang secara online streaming untuk kesatuan audio-video.

\section{Proses Penayangan}

Uji tayang dilakukan pada tanggal 14 dan 15 Maret untuk memastikan tidak ada kendala jaringan maupun file yang sudah dikirim. Uji tayang dicoba pada platform twitch, youtube, go-play dan loket.com. Setelah uji tayang dinyatakan layak, tanggal 16 Maret 2021 dilakukan penayangan resmi perdana konser virtual "Colorchestra" pada platform loket.com dan aplikasi Go-Play. Tiket dijual melalui website Loket.com dan aplikasi GoTix. Setiap audiens yang telah melakukan pembayaran mendapatkan link ekslusif untuk membuka tayangan konser. Link tersebut terbatas untuk digunakan hanya pada 1 gawai. 


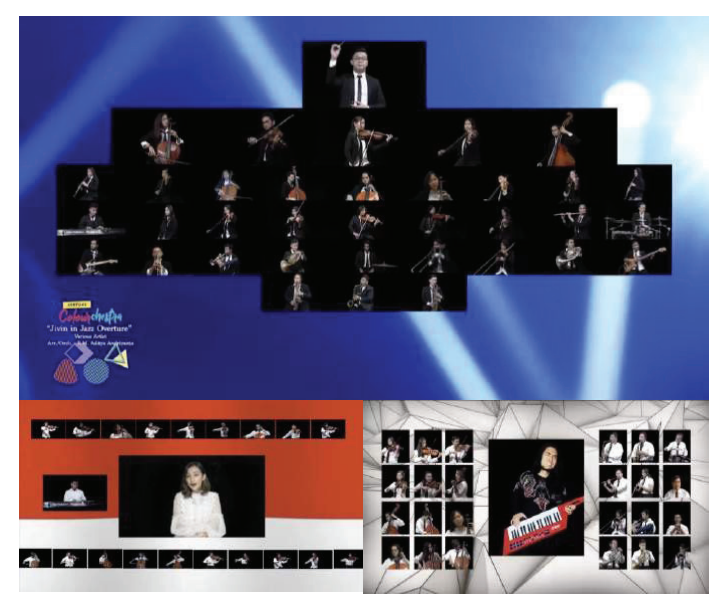

Gambar 27. Penayangan Perdana Konser Virtual "Colorchestra" BCO. (Sumber: dokumentasi Loket.com)

\section{KESIMPULAN}

Pada konser virtual Batavia Chamber Orchestra "Colorchestra" yang ditayangkan secara daring melalui platform digital loket. com, audio dan video sudah diproduksi sebelum penayangannya. Tahapan produksi audio yang dilakukan diantaranya proses rekam audio, editing audio, mixing dan mastering yang dilakukan pada DAW Logic Pro. Proses rekam audio dan video dilakukan secara terpisah dengan merekam pemain secara satu-persatu, kemudian file audio digabungkan dan di-edit menggunakan DAW. Interpretasi konduktor pada penampilan orkestra dicapai melalui proses mixing dan mastering melalui pengolahan estetis frekuensi, dinamika dan panorama menggunakan berbagai plugin yang terdapat pada DAW Logic Pro. Logic Pro terbukti mampu digunakan pada keseluruhan rangkaian proses produksi audio konser virtual. Hasil akhir audio selanjutnya digabungkan dengan produksi video untuk kemudian ditayangkan menjadi kesatuan konser virtual "Colorchestra" Batavia Chamber Orchestra.

Dari paparan konser virtual diatas, didapati bahwa seni pertunjukkan musik orkestra sedang memberikan alternatif penyajian karya, yaitu tayangan secara virtual. Fenomena ini menjadi sebuah perubahan kebudayaan dalam bermusik, baik di Indonesia maupun dunia. Berdasarkan penelitian ini, perkembangan musik juga terjadi dari sisi teknologi yang digunakan. Sekarang ini memproduksi karya musik dapat dilakukan lebih efektif dan efisien melalui pemanfaatan teknologi digital DAW. Dunia seni musik semakin berkembang khususnya dalam berkarya dan menyajikan pertunjukkan musik.

Demi memperoleh outcome yang semakin baik, sebaiknya pertunjukkan konser virtual terus dilakukan, diselenggarakan dan dieksplorasi potensinya. Upayanya dapat berupa adanya festival atau lomba penyajian karya secara virtual. Ataupun dengan adanya pembelajaran seperti perkuliahan teknologi musik ataupun pelatihan-pelatihan dengan materi serupa. Selain itu, dapat pula dilakukan peningkatan kompetensi guru, dosen pengajar, seperti diikut sertakan dalam pelatihan atau kursus singkat terkait musik digital khususnya mengenai Digital Audio Workstation Logic Pro. Terakhir, diharapkan adanya penelitian lanjutan terkait pemanfaatan DAW pada konser virtual tingkat pelajar dan mahasiswa, agar literasi digital dalam dunia akademis pendidikan musik di Indonesia semakin maju lagi.

\section{REFERENSI}

Adolph, Martin. 2009. Mobile Applications, International Telecommunication Union-T TechWatch.

Andriyanto, R. M. A. (2020). Peningkatan Kompetensi Mahasiswa Teknologi Musik Melalui Penerapan Pembelajaran Software Digital Audio Workstation. Grenek: Jurnal Seni Musik, 9(2), 1528.

Hardiman, A. (2020). Buku Kitab Sakti Music Content Creator. PT.Sonica Music International. 
Karpati, A. (2011). Digital Literacy: Content, Structure and Development of a Life Skill.

May.

Nahmani, D. (2015). Apple Pro Training Sereis : Logic Pro X 10.1 (B. Lindstrom (ed.)). Peachpit Press.

Septiyan, D. D. (2020). Perubahan Budaya Musik Di Tengah Pandemi Covid-19.

Musikolastika: Jurnal Pertunjukan Dan Pendidikan Musik, 2(1), 31-38. https://doi. org/10.24036/musikolastika.v2i1.37

Bauer, Harald, dkk. 2015. Industry 4.0: How to Navigate Digitalization of The Manufacturing Sector. McKinsey Digital, McKinsey \& Co.

Dye, Charles. 2008. Digital Audio Workstation Guidelines for Music Production. Florida: The Recording Academy Producers and Engineers Wing.

Ewer, Gary. 2005, The Essential Secrets of Songwriting, Pantomime Musik Publication, Canada.

Hardiman, A. (2020). Buku Kitab Sakti Music Content Creator. PT.Sonica Music International.

Hill, Brad. 1998. Going Digital: A Musician's Guide to Technology. USA: Schirmer Books.

Karpati, Andrea. 2011. Digital Literacy in Education. UNESCO Institute for Information Technologies in Education.

Manyika, James, dkk. 2017. A Future That Works: Automation, Employment, and Productivity, Mckinsey Global Institute.
Nart, Sevan. 2016. Music Software in the Technology Integrated Music Education,

TOJET: The Turkish Online Journal of Educational Technology. 15(2): 78-84.

Ojala, Aleksi. 2017. Learning Through Producing: The Pedagogical and Technological Redesign of a Compulsory Music Course for Finnish General Upper Secondary Schools, Finland: The Sibelius Academy of The University of The Arts Helsinski. Prensky, Marc. 2001. Digital Natives, Digital Immigrants. On the Horizon ( $M C B$

University Press. 9(5):1-6.

Wena, Made. 2011. Strategi Pembelajaran Inovatif Kontemporer. Bumi Aksara, Jakarta Timur.

Williams, David Brian, Peter Richard Webster. (1999), Experiencing Music Technology, Schirmer Books, USA.

Buku Acara Konser BCO "Musik Untuk Ananda" 2015

\section{Webtografi:}

https://www.apple.com/logic-pro/ https:// www.thejakartapost.com/life/2020/05/14/playing-it-forward-virtual-concerts- offer-new-way-to-enjoymusic-while-helping-others.html https://media.neliti.com/media/publications/78207-ID-pemanfaatan-mediadalam- proses-belajar-m.pdf

http://www.openprojects.org/software-definition.htm www.unj.ac.id 